\title{
The Church and Constitutional Reforms in Kenya, 1992-2002: A Retrospective-Historical Analysis
}

\author{
Stephen Asol Kapinde (M.A)
}

Doctoral Assistant, Faculty of Theology, University of Basel, Switzerland Research Associate, Centre for African Studies (CAS), Basel

Doi: 10.19044/esj.2018.v14n5p216 URL:http://dx.doi.org/10.19044/esj.2018.v14n5p216

\begin{abstract}
Religious leaders have played a leading role in the struggle for constitutional reforms in Kenya since 1990s.Significantly, they have argued over time that the constitution is the covenant of the nation and the "moral placenta' of any meaningful democratic governance. This article therefore sets out to examine the mid-wifery role of religious leaders in negotiating for constitutional reforms in an attempt at consolidating democratic gains achieved following the repeal of section $2 \mathrm{~A}$ of the then constitution on $19^{\text {th }}$ December, 1991. The article is alive to the fact that the struggle for constitutional change in Kenya was an 'hybrid enterprise' which empirically cannot be analyzed by a single actor, entity or factor since many groups whether religious or civil society contributed in their own way in fighting for civil liberties and human rights. Methodologically, this is a retrospectivehistorical analysis of the contribution of the Church in the wider debate of constitutional making process between 1992 and 2002. The central question being addressed is on how the Church played out its activism in the glamour for constitutional reforms. It sets out on the premise that their activism towards constitutional reforms was undergirded by reconstruction paradigm as articulated by African Theo-philosophers such as Jesse Ndwiga Mugambi. Reconstruction paradigm is a theological trajectory that builds on the EzraNehemiah motif. The article relies on archival sources as well as seven indepth oral interviews with key informants.
\end{abstract}

Keywords: Church, Constitutional reforms, Democracy, Reconstruction theology, Ufungamano Initiative

\section{Introduction}

On $19^{\text {th }}$ December, 1991, the National Assembly of Kenya repealed the contentious Session 2 A of the then Constitution putting an end to street demonstration and 'pulpit pressure' that had characterized the struggle for 
multi-party democracy in Kenya. Daniel Torotich Arap Moi, the second president of the Republic of Kenya (1978-2002) capitulated to both domestic and international pressure on party pluralism, hoping that with the reemergence of party pluralism his reign would be peaceful without a series of bloody street demonstration and picketing that marked the sun set period of 1990s (Brown, 2001; Kapinde, 2015). However, this was not the case as the struggle shifted immediately from party pluralism debates to calls for constitutional reforms.

This article therefore, examines the contribution of the Kenyan Church leadership in calling for constitutional reforms. The study is alive to the fact that some of the Evangelical right wing Protestant Church leadership distanced themselves from the political debates with regard to constitution reforms with others siding with the State later changed tune following the defeat of KANU in 2002 and became active in political discourses with some opposing the rectification and promulgation of the 2010 Kenya's constitution. The article is interested in the period between 1992 and 2002 because it acted as a precursor to later constitutional agitations in Kenya. More significantly however, the period set the agenda for the National Alliance Rainbow Coalition (NARC) regime which came to power later in 2002 following the retirement of president Moi. The period also exemplifies the mid-wifery role of the Church and religious leaders in the struggle for constitutional reforms. I considered this period as the 'age of reformation' in Kenya since the primary focus of the Church, religious leadership, and the civil society was on constitutional reforms in the wider context of reconstruction paradigm.

\section{Socio-Political and Theoretical Contours}

Prior to these calls for constitutional reforms, President Moi like his predecessor; Jomo Kenyatta (1963-1978) had carried rudimental amendments on the 1963 Independence Constitution. Such that they gradually dismantled key clauses on civil liberties, freedoms, democracy and human rights. It is some of these amendments on the constitution such as the one on $9^{\text {th }}$ June, 1982 which turned Kenya into a de jure, one party State that angered individual clerics from 'mission established Churches" 3 to denounce Moi's misrule (Kapinde, 2015). Therefore, the call for constitutional reforms was one of the major reconstruction projects undertaken in the history of ChurchState engagement in Kenya. This is echoed in Jesse Mugambi's call for a shift in theological paradigms from liberation to reconstruction motif anchored on the Ezra-Nehemiah text (Mugambi, 1995, Gathogo, 2007 and Kapinde, 2015). Mugambi argues that reconstruction paradigm should be the modus operandie

\footnotetext{
${ }^{3}$ Mission established Churches were mainline orthodox Churches that preceded the colonial rule in Africa.
} 
of analyzing African theological discourses rather than liberation paradigm which characterised the entire colonial and cold war period (Mugambi,1991:199). He suggested further that in the New dispensation, "the figure of prophet Nehemiah, unlike that of Moses, provides us with a mirror through which we can see our endeavours to rebuild Africa out of the ruins of wars against racism, colonial domination, single party dictatorship, military rule, poverty, economic mismanagement, corruption, neo-colonialism and ideological branding (Mugambi, 1995:160-180).

Coincidentally, Mugambi's call for reconstruction model signified the collapse of military rule in most countries in Africa, and apartheid regime in South Africa as well as the end of one party dictatorship in Kenya as in most countries of Sub-Saharan Africa (Ibid.). To some theological commentators such as Julius Gathogo, the re-emergence of reconstruction paradigm at a time when Church clerics were calling for constitutional reforms was appropriate for the social, economic, and political development of Kenya (Gathogo, 2008). Gathogo notes that reconstruction is the major theological paradigm over liberation and other minor discourses such as African feminist theology, Black South Africa theology, and inculturation theologies in the Post-Cold war Africa (O.1 on 19/02/2015).

Others such as Tinyiko Maluleke and Joseph Wandera were skeptical about reconstruction praxis as they saw the whole idea to be immature, foreign and suspicious. Maluleke in particular is pessimistic of Mugambi's motive with reconstruction and interrogates its viability. However, he admitted the prominence of the debate when he observed that, "Reconstruction, development, and democracy are fast becoming as integral to South African political language as the notions of the struggle, revolution and liberation used to (Maluleke, 1994;245-258). This article however, found that such constructive criticisms do not necessarily negate the essential dominance of reconstruction paradigm especially in the call for constitutional reforms in Kenya as in many countries in Africa in post-cold war era.

\section{Setting the Constitutional Agenda}

The 1992, multi-party general elections were held and the incumbent, President Moi won the elections narrowly with only $37.3 \%$ of the total valid votes cast over a deeply divided opposition (Kapinde, 2015). The disunity among the opposition leaders was partly due to the resurgence of ethnocentrism which characterized the democratic transition and has remained unabated in Kenyan politics to date. However, the 'invisible hand' of president Moi is not overruled as he was accused of bankrolling some opposition leaders such as Kenneth Matiba to divide the populace Agikuyu vote to the detriment of a united opposition (Throup \& Hornsby, 1998;412-413). Prior the reintroduction of multi-party politics, Moi had consolidated his position through 
a single party, Kenya African National Union (KANU), however with the return of party pluralism; he shifted to politics of ethnicity and perfected it with clientism/patronage. ${ }^{4}$ And in cases where he and his cronies felt that violence was a necessity, they would not hesitate to use it. To him the end justifies the means parlance was his political slogan (Kapinde, 2015). Drawing on ethnicity and democracy, Donald Horowitz contends that the spirit of competition which may be seen as healthy in a multi-party democracy; anchoring the same on ethnic nationalism may prove to be counter-productive (Horowitz, 1994). Since, ethnic rivalry may negate the developmental agenda of democracy in Africa (Ibid). Historically, multi-party democracy in Kenya was anchored on ethnic amalgamation, and mobilisation. Clearly, then political coalition(s) in the country are rather ethnic and /or intra-ethnic coalitions whereby the political elites appropriate their 'ethnic good will' for selfish gains (Kapinde, 2015). In such cases ethnic manifestoes are primary to national agenda and subsequently, the constitution is often disregarded to achieve myopic ethnic agenda.

Regarding the 1992 multi-party elections, the opposition rejected the results terming them rigged in favour of the incumbent. According to John Henry Okullu (former Bishop of Anglican Church, Maseno South Diocese) the rejection of the election results sent shock waves all over the world. It got extensive media coverage locally and internationally (Okullu, 1997;138). In response to opposition's outcry, the religious community ${ }^{5}$ urged for the acceptance of the results despite "overwhelming evidence" indicating the incumbent had "desperately manipulated the election to retain power (Daily Nation, January 4, 1993)." A case in point is the late Archbishop of the Anglican Church of Kenya (1997-2002), David Gitari in his true nature of appreciating the values of democracy urged the opposition to accept the results (Mathenge, O.I, 29/01/2015). Gitari said; "it is better to accept a slightly rigged election than to have absolute chaos as an alternative (Ibid)." Adding his voice, Bishop Okullu Stated:

My plea is, therefore, to the opposition parties to look beyond the rigged elections for intelligent, patriotic and peaceful arrangements to achieve through parliament what has been denied through the ballot box. Democratization is slow, painful, and frustrating process. Kenyans has come a long way in only one year. Let us cherish what we have achieved: the freedom to speak our mind without fear of arrest, the prospect

\footnotetext{
${ }^{4}$ Government appointments as in parastatal jobs were issued out along ethnic lines to entice different leaders to support the government regardless of serious issues such as corruption and ethnic violence that marked the re-emergence of multi-partism.

${ }^{5}$ NCCK and the Catholic - Justice and Peace Commission, were members of a three-body observer team funded by donors (Daily Nation, January 4 1998)
} 
of a multi-party legislature. Our resolve to resist evil should not bind us from these important victories (Okullu, 1997;139).

Apparently, both Statements from Okullu and Gitari were mediating and reconstructing in contrast to the 2007/2008 post poll conflict in Kenya where religious leaders abdicated their God-given duties to 'tribal chiefs' by remaining silent, as the country was torn apart by ethnic violence. ${ }^{6}$ However, it is important to note that the flawed nature of Kenya's 1992 transition $^{7}$ to democracy cannot solely be attributed to the unwillingness of the Moi administration to institute tangible structural and constitutional reforms for democratization. It is fair to argue that in many respects, political parties of the opposition also contributed to the perpetuation of oppression and authoritarianism in the country (Mutunga, 2000;28). Willy Mutunga (the former President of Supreme Court of Kenya, 2008-2016) argues that a number of the pro-democracy and human rights groups as well as religious organizations tried in vain to convince the opposition parties not to participate in the elections before comprehensive reforms of the Constitution in contrast to minimum reforms championed by politicians and the government for narrow political ends (Ibid).

On account of the aborted State transition and transformation following this election, and the elusive unity of the opposition in calling for comprehensive constitutional reforms. That made the Church, individual clergy, civil society and other religious groups to waiver in the debate for constitutional reforms. It is this failed transformation and transition that rekindled the lost memories of Constitutional Review that had begun in the nascent period of 1990s and faded immediately when Moi capitulated to multiparty politics. But of utmost significance here is how the failed transition and transformation redefined the future Church-State engagement with reference to constitutional reforms?

In the aftermath of the opposition defeat, the Church refrained from direct engagement in the opposition affairs neither did they constructively engage the government on issues of public interest (Mathenge, O.I, 29/01/2015). But still, some individual clerics from mainline Churches such as Timothy Njoya, Gideon Ireri and Henry Okullu, together with other leaders from Law Society of Kenya (LSK) and other Civil Society Organization

\footnotetext{
${ }^{6}$ The dichotomy of the word de-construction is that it can have both negative and positive connotations. Here it has been used in a negative perspective to refer to the ethnic violence that characterized the nation following post election violence. On a positive note the term can refer to uprooting of structures of bondage. As in the case of liberation framework, deconstruction is actively undertaken for people to be liberated.

${ }^{7}$ Guillermo O’Donnell and Philippe Schmitter (1986:6) define a transition as "the interval between one political system and another". For the case of Kenya, it was a change from one party governance /dictatorship to multi-party politics.
} 
(CSOs) piled the pressure on the government to review the constitution (Ibid). Of the Church leaders, Okullu was very conspicuous on political issues and could be seen as an independent voice with his own political ideologies; a trait he shared with Timothy Njoya as they both developed a theology of power (Kapinde, 2015). On the other hand, Gitari appeared to be very much concerned with the 'eternal political drama' in Kirinyaga District henceforth, missing inaction at the national level (Muriuki \& Mararo, O.I; 30/01/2015). In the absence of Gitari, Gideon Ireri (former bishop of Mbeere, 1998-2008) had virtually placed himself as one of the key actors within the Anglican Justice and Peace Commission (AJPC) and was leading in the campaign for constitution review (Ireri, O.I; 10/04/2015). However, this article found such efforts to be limited unless the political class were fully incorporated in the process. This is partly because the attitude of many politicians in Africa and Kenya in particular is that they would want to lead and control all process of political nature and that often than not they would scuttle transformational processes when not involved or dictate the terms even if they are unconstitutional.

Two years down the line, and KANU still in power enjoying the same status as back in 1980s though in a different political dispensation, Church leaders realized that the constitution was the 'moral placenta' of democracy in developing nations and that without constitutional reforms, the gains of multipartism which they had fought for during the second liberation could not be fully realized (Mathenge, O.I, 29/01/2015). Similar sentiments were shared by the politician and therefore they began to demand for minimum reforms. Bishop Gitari writes that this time they were not willing to go for another election in December 1997 without minimum constitutional reforms (Gitari, 2014;258). However, this change of orientation was informed by their feeling that the constitution as it existed tilted the political landscape in favour of the ruling party, KANU. And they hoped that Constitutional reforms would guarantee them the best shot at the presidency (Ng'ethe \& Katumanga, 2003).

Attempting to rebuild his tarnished image, the president shocked the nation on $31^{\text {st }}$ December, 1995 by announcing from Nakuru State House that he would invite foreign experts to review the constitution and hand over the draft to parliament for debate and ratification (Mutua, 2008;74). Perhaps, Moi being a 'Professor of politics' was 'applying brakes' to the process of constitutional making of the country which was gradually gaining momentum, day after day and especially with the involvement of the civil society, religious leaders, and opposition parties (Mathenge, O.I, 29/01/2015). James Mathenge in an interview with the researcher elaborated this further that Moi had realized that the struggle for constitutional change could have taken a similar twist as the battle for party-pluralism which began as a peaceful individual resistance, and evolved to a mass protest, henceforth, getting the backing of the 
international community (Ibid). By all means, the regime was worried of domestic resistance in de-legitimization of the State to the international community as witnessed in aid freeze prior multi-partism (Press, 2013).

Such a move, however, could not deter the spirit of nationalism that had been entrenched in some Civil Society Organisations (CSOs) such as Coalition for National Convention (CNC) and Citizens Coalition for Constitutional Change (4C's). In spite of the assurance, Jacob Mati observed that 'Moi's pronouncement turned out to be just hot air meant to steal thunder from middle class civil society groups' coalescing around the $4 \mathrm{Cs}$, and their published proposal for a 'Model Constitution' that had captured a lot of public imagination (Mati, 2012;127). Nonetheless, he argues that Moi's announcement provided a political opportunity for greater mobilization of more forces in the question of Constitution Reforms (Ibid).

Of grand significance, and as the article shall demonstrate further is the involvement of the clergy from the major religious groups, drawn mainly from mainstream Protestant Churches affiliated to National Council of Churches of Kenya (NCCK) and the Roman Catholic Church (RCC). Furthermore, other umbrella organisations that emerged prior the end of 1996, such as National Convention Assembly (NCA) and its steering committee, National Convention Preparatory Committee (NCPC) ${ }^{\prime 8}$ bringing together all NGOs, and political parties were also animated by the religious group with an exception of KANU which had been sidelined from the onset (Ireri, O.I;10/04/2015). Despite the involvement of the religious sector in the constitution bandwagon, their participation was lukewarm and only picked up during the Ufungamano Initiative. Citing Musambayi Katumanga, the clergy had been made by the regime to believe that their role was to mediate between oppositional parties, and civil society on one hand, and the government on the other side (Katumanga, 1999). He observes correctly that such a move was aimed at preventing any unity of purpose between the religious sector and the opposition (Ibid). In doing so, Moi perfected on the divide and rule tactic employing ethnicity, and sometimes backed up by clientistic politics to the disadvantage of reform groups.

In view of the foregoing discussion, NCA transformed its steering council, NCPC into an executive arm, henceforth, the National Convention Executive Council (NCEC) which presided over a series of violent protest rallies and other forms of mass action and civil disobedience within major towns in Kenya popularly known as Saba Saba. ${ }^{9}$ Mati writes that from then on

\footnotetext{
${ }^{8}$ For more on NCA and NCEC read Willy Mutunga' book entitled: Constitution Making from the Middle (1999). He explored on the process of constitution making in Kenya and examined the opportunities, successes and challenges that characterized the process and also the general civil society role in participatory democracy.

${ }^{9}$ Saba saba or 'Seven Seven' protest were held on $7^{\text {th }}$ July of every month throughout 1990 s.
} 
the clarion call from NCEC was 'No Reforms No Elections (Mati, 2012;135).' According to Winnie Mitulla this was aimed at pressurizing the government into conceding and instituting the process of constitutional reforms before the December 1997 elections (Mitulla, 2003;212-235). However, of equal importance to the study is the violent nature of the protests as it seemed to be 'a bait set for the regime' to react with force in order for the movement to gain legitimacy and sympathy from the public and henceforth de-legitimaze the State which had claimed to have won the previous election fairly (Katumanga, 1999). Underlying such defiance, Katumanga argues that the public would understand not only the type and nature of regime that ran the State, but the issues under contestation would also find resonance in the public domain (Ibid).

\section{The Bloody Protest and the Church on Retreat}

As the General election in 1997 approached, president Moi accepted minimum reforms in the constitution as demanded by the opposition under the Inter-Parliamentary Parties Group (IPPG) chaired by Raila Odinga then leader of National Democratic Party (NDP). The acceptance of minimum reforms prior election by the politicians was seen as a by partisan approach, however to the religious leaders this was a 'cosmetic surgery' to the constitution (Kapinde, 2015). Since the contentious underlying issues could only be addressed through comprehensive reforms. It should also be understood that this was not the first betrayal of the Church and civil society groups by the politicians but rather a demonstration that the opposition just like the government were only interested in acquisition of power and had no national agenda at heart. Therefore, the Church backtracked on commenting on political issues with a few individual Church clerics such as Timothy Njoya and Henry Okullu participating in constitutional debates but under the banner of civil society. Meanwhile, civil society groups mainly NEC with a few religious leaders such as Njoya intensified street demonstrations which often turned chaotic (see figure 1). 


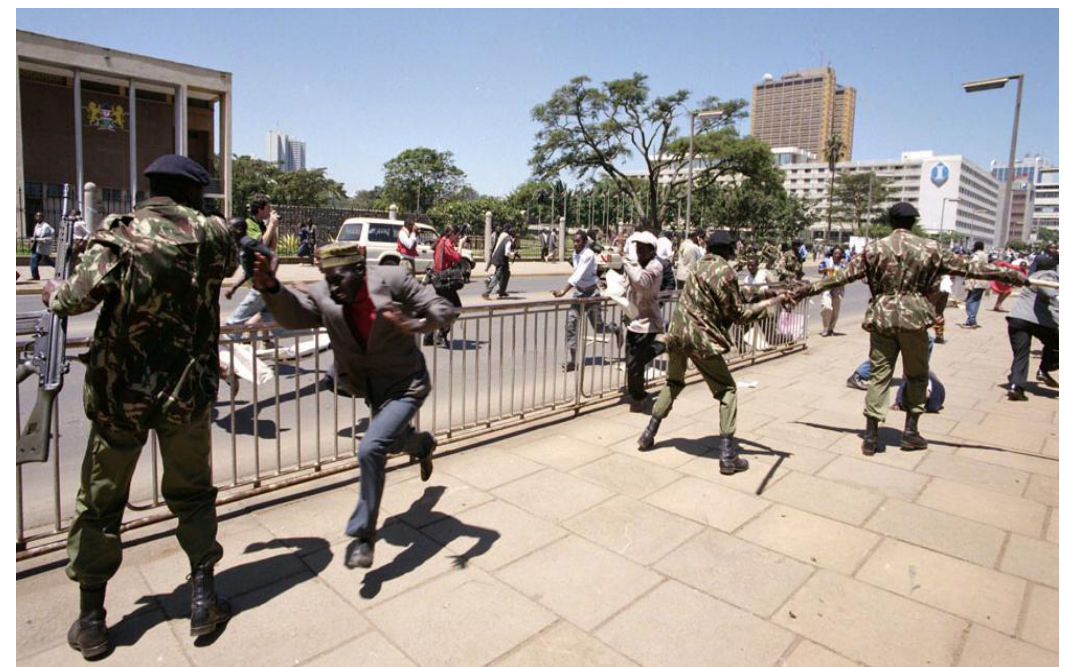

Fig.1: Police attack demonstrators outside parliament buildings on Saba-Saba, 1997 (Adapted from Jacob Mati, 2012;138)

When commenting on street protests, Gideon Ireri in an interview with the researcher observed that Seventh, July, 1997, which came to be called Saba-Saba was a dark day for National Convention Executive Council (NCEC) and some religious leaders (Ireri, O.I; 14/04/2015). As usual, NCEC had organized demonstration in the city to compel the government to consider their views on constitutional review. However, the police descended on demonstrators who had taken refuge at All Saints Cathedral Anglican Church of Kenya (at the CBD of Nairobi), tear gassed and beaten many people, including several opposition politicians, the clergy and leaders of NCEC (Gitari et al, 2002;83). On this incidence, Mati argues that the greatest casualty were two key members of NCEC, namely, Kepta Ombati and Rev. Timothy Njoya who were seriously clobbered and maimed (Mati, 2012;136). He further observes that blood was spewed everywhere in the Church whilst used teargas canisters also lay everywhere inside the building ( $I b i d$ ). Outside, fourteen people had been shot dead including five university students (Katumanga, 1999). However, this number is disputed as Timothy Njoya claimed that twenty-one people lost their lives in this mayhem (Njoya, O. I; 29/07/2002). Numbers notwithstanding, police brutality against the harmless demonstrators exposed how desperate the regime was in curtailing the reform process.

According to Katumanga the net effect of the regime repression and brutality as witnessed during the Saba-Saba had been the key objective of NCEC from the onset; that is (was), to legitimize the reform process while conversely de-legitimizing the State as a result of its anti-reform activities, especially predatory violence against civilians (Katumanga, 1999). It is in the foregoing context that the Church and religious leaders emerged in the 
constitution agenda under the banner of the Peoples Commission of Kenya (PCK) which was popularly known as the Ufungamano Initiative.

This article established that on the strategy of tarnishing the regimes image, NCEC succeeded, as the heightened State intolerance was condemned worldwide by spiritual and political leaders alike (Ireri, O.I; 14/04/2015).Global Anglican leaders including Rowan Williams, Michael Geoffrey Peers, Bundo Kim and Anglican UN ambassador, James Hamilton Ottley protested State brutality against citizens. In an open protest letter to President Moi, Rowan Williams, the former Archbishop of Canterbury (Anglican Church, England) wrote:

It is with great dismay and sorrow that we read of a police attack on the worshippers at the Cathedral in Nairobi on July $7^{\text {th }}$. Christian buildings have always been regarded as sanctuaries in which violence was outlawed, and it seems only right that there should be public assurance that a Church should not be violated again (Gitari et al., 2002;100).

On his part, Michael Geoffrey Peers, the Anglican Primate of Canada (1986 - 2004) went as far as demanding an apology from the government. Part of his letter says; "I am distressed by action that harasses worshippers who gather to pray for the well-being of your country. I join my voice with others around the world to protest acts of violence carried out against people who are gathered peacefully. I hope you will disassociate yourself from such action by making an apology on behalf of the government to the leaders of All Saints Cathedral (Gitari et al., 2002;100-102)." Arguing along these lines, Bishop Bundo Kim, Primate of the Anglican Church of Korea charged; "it is regrettable that Kenyan police force invaded the Temple of God, destroyed the Church facilities, shot barrages of tear gas bullets, inflicted violence and arrested innocent citizens who sought refuge in the Church. We believe that a power that fails to respect the Church cannot last long. We urge your government to render an apology (Gitari et al., 2002;102).', Others such as Rev. James Hamilton Ottley, the then Anglican observer at the United Nations (UN) called for thorough investigation over police brutality. He also requested president Moi to use his offices to take specific measures which can prevent such occurrence in the future (Ibid, 105).

Drawing upon this sacrilegious act, Moi had proved that the Church was no longer sanctuaries. Whilst giving his testimony during the cleansing ceremony, Hon. Kamau Icharia (Member of Parliament for Kiambaa Constituency) claimed that during the Mau Mau War of Independence (19521960) some freedom fighters took refuge in a Church and the British soldiers pursuing them did not enter due to the attachment bestowed on the temple of God (Mutunga, 2013). This was contrary to 1980s whereby despite State censorship and limited freedom of speech, the Church was a privileged 
institution as the clerics engaged in peaceful resistance through the pulpit without any fear of arrest and detention (Muoki \& Kapinde, 2016). However, this time round Moi was sending a signal to the Church that "politics is a dirty game' and I had warned you.

A week later, on $13^{\text {th }}$ July, 1997, Archbishop David Gitari (the bishop and cleric in-charge of All Saints Cathedral) responded to Moi's 'zealots' and their sacrilegious act in a desecration ceremony in the Church attended by thousands of people (Gitari, 2014;259-262). He purposefully preached from the book of Daniel chapter 5; a sermon entitled: 'Mene Mene Tekel, Parsin' (Gitari et al., 2002;83). Gitari and other prelates of ACK began by cleansing the cathedral using blessed water- all round, in a colourful inclusive procession of clergy, lay leaders and members of the congregation as shown in figure 2 below (Gitari, 2014; 259-262).

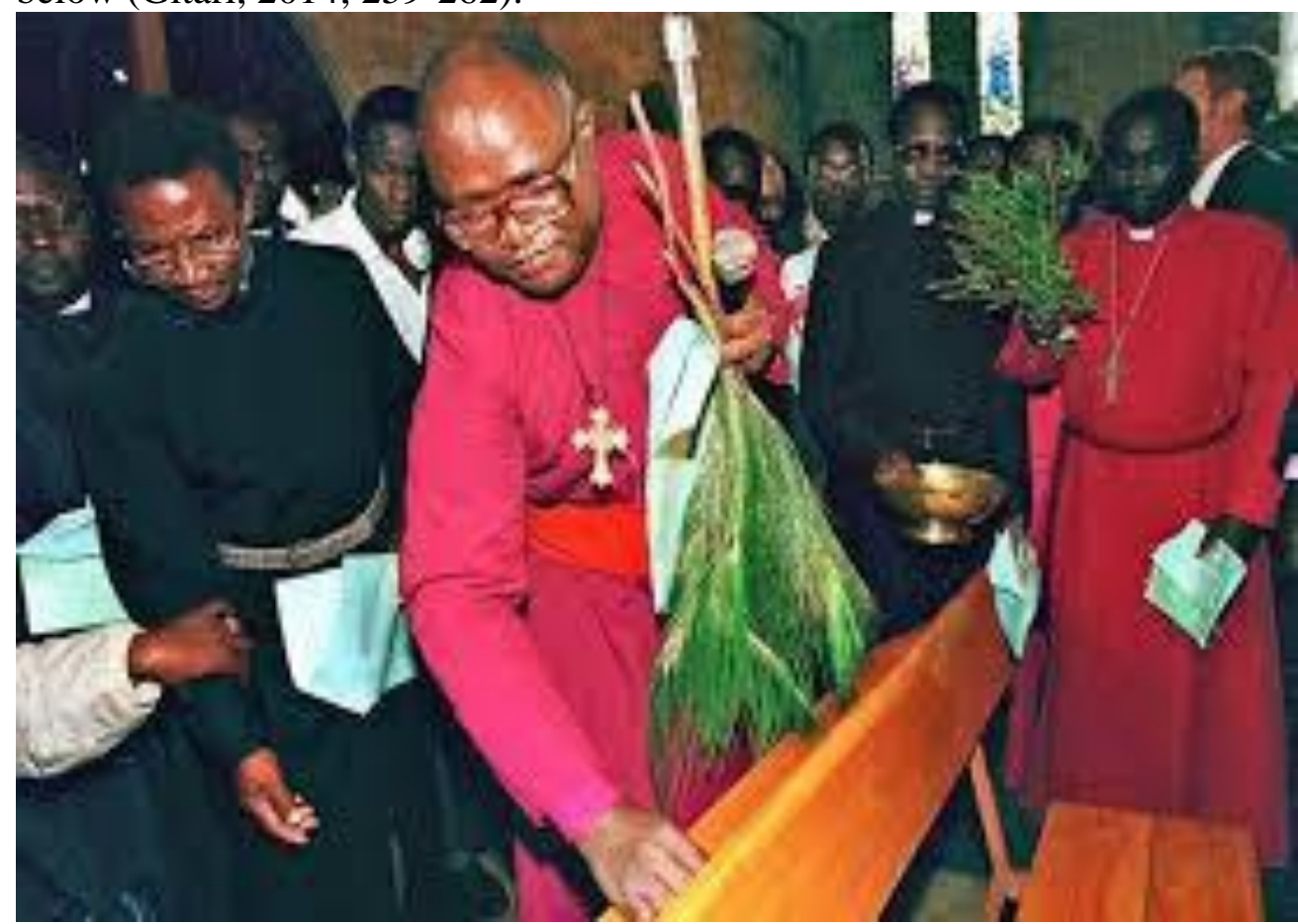

Fig.2: Archbishop David Gitari Cleansing the All Saint Cathedral, Nairobi (Picture courtesy of John Mwendwa)

After desecration, Gitari embarked on exposition of the book of Daniel Chapter 5. In his exposition, Gitari had paralleled the socio-political context of Kenya to Babylon and how the reign of King Nebuchadnezzar and his son Belshazzar ended prematurely (Ireri, O.I; 14/04/2015). Willy Mutunga in his eulogy to the late Gitari acknowledged that this was the greatest political sermon that had ever been preached in Kenya (Mutunga, 2013). He stressed that; "for the majority of people who attended the service, the words; "Mene 
Mene Tekel Uparsin" will never be forgotten. Moreover, their interpretation was given again and again, and by the time Gitari finished his sermon, they had been committed to the memory of all, even for those in attendance who may have had poor memories (Mutunga, 2013). This powerful solemn and provocative sermon was preceded by the song, "Onward Christian Soldiers," and that had the prelate hesitated, Christians/congregants could have marched to State House to oust president Moi (Ibid).

The above exposition of the book of Daniel was a clear warning to Moi that his days in office were numbered and his fall inevitable. Gitari avers that, 'I told the president that the hand of God had not yet written; "Mene Mene, Tekel Uparsin (Gitari, 2014;260) but if those in authority (Moi) refuse dialogue and fail to hear the cries of the people and continue to harden their hearts then the hand of God would write on the wall of State House (Gitari et al., 2002;93)."

In the midst of these domestic and international condemnations and fear that the donor community could call for economic sanctions, president Moi capitulated to Gitari's sermon on $15^{\text {th }}$ July, 1997 by inviting some religious leaders to State House for a dialogue (Mati, 2012;141). The call for dialogue was in line with the reconstruction model articulated by Mugambi as both the 'oppressor and the oppressed' are involved in deconstruction of oppressive structures. In spite of such a move, Gitari and other religious leaders were very skeptical of this invitation because all along they believed Moi was a 'political conman' and was always backtracking on his words as in the case of his Nakuru declaration when he promised to invite international experts to review the constitution (Mathenge, O.I, 29/01/2015). True to his words, Mati observes that Moi allegedly sought the clergy's help in containing the NCEC tide with a promise that he was now for reforms (Mati, 2012;141). However, according to Mutunga, Gitari was persuaded to accompany his brethren to State House against his better judgment since he was fully aware of the 'cunning nature' of the president (Mutunga, 2013).

Despite such reservations, their attendance was not in vain as the president conceded to some of the clerics demand (Ireri, O.I; 14/04/2015). Gitari said: "the president told us that he had accepted the constitution to be amended before the December polls. He also requested the clerics to mediate between the opposition MPs and government ministers on how to review the constitution (Gitari, 2014; 262)." However, it is important to observe that these concessions made by the State cannot be solely attributed to the clergy's activism rather the international condemnation and the street protests as well. Gideon Ireri acknowledged that the cleansing of the Church by Gitari and worldwide condemnation of State brutality forced Moi to soften his stance (Ibid). James Mathenge corroborated this further when he observed that Moi being a 'Church goer' might have been fully informed on the context and 
content of the sermon and its implication to his reign (Mathenge, O.I, 29/01/2015). The article contends here that the Church as a social institution had a voice and force to compel and direct the regime's behavior towards a particular direction though with some limitations.

What is intriguing in the quest for constitutional reforms in Kenya is how Moi managed to manipulate different pressure groups through different strategies including ethnicity, violence, arrest and detention of members of NCEC and co-optation (Ireri, O.I; 14/04/2015). The latest casualty of Moi's political machination was the clergy as they were perceived by the regime as mediators between NCEC and KANU. Demonstrating his sincerity and desire to reconstruct the image of his government to the international community and donor nations, Moi went as far as agreeing to the enactment of a law in parliament, the Constitution of Kenya Review Act, 1997 (Mati, 2012;141). Moreover, he acquiesced to minimum reforms negotiated by Inter Parliamentary Parties Group (IPPG) with a promise that comprehensive reforms would follow after the 1997 - General election (Ibid).

After the elections, Moi backtracked and was no longer interested in comprehensive reforms hence confirming Gitari's worst fears over negotiation with the regime and especially moving closer to Moi as it exposed the clergy to co-optation, henceforth weakening their prophetic voices (Ireri, O.I; 14/04/2015). The opposition members of parliament were also not immune to such co-optation as National Development Party (NDP) led by Raila Odinga and Ford Kenya of Kijana Wamalwa also crossed the floor to join the government (Ibid). Such undertakings punctured the 'wheels of constitution making.' Consequently, the struggle became slow but also posed a challenge to NCEC which was becoming popular with the citizens on the grass root as well as urban dwellers. On this betrayal by the political class, Mutua argues that a majority of the opposition politicians were already feeling irrelevant as NCEC was firmly in control of the struggles, the mobilization structures, and networks (Mutua, 2008). However, foreign diplomats and the donor community also played a role in persuading the opposition MPs to join the IPPGs meetings which were being chaired by Raila to the disadvantage of NCEC. This only confirmed Stephen Brown's contestation that the donor nations subverted meaningful transformations in the country. ${ }^{10} \mathrm{~A}$ trend that has continued in Post-Nyayo era, where foreign donors will rather endorse undemocratic processes as long it serves western agenda.

Meanwhile, KANU and the IPPG failed to institute any meaningful reforms as the president usurped powers through the office of the then

\footnotetext{
${ }^{10}$ For a detailed study on how the foreign powers and the donor community helped to keep Moi in power see Stephen Brown, (2001) Authoritarian leaders and multiparty elections in Africa: How foreign Donors help to keep Kenya's Daniel Arap Moi in power. Third World Quarterly. Vol. 22 (5): pp.725-739.
} 
Attorney- General Amos Wako, leaving some radical opposition members with no option but to walk out of the talks (Chitris, O.I 08/07/2015). On the other hand, NCEC re-organized itself and continued with what Jacob Mati referred as 'pressure politics' namely mass protests which did not augur well with the religious leaders such as Gitari due its chaotic nature (Mati, 2012;143). In the view of the aforementioned, it is noteworthy that the Church has and can continue to play a critical role in opening up space for debate, and democratization, however, it is not immune to State co-optation. In the struggle for constitutional reforms the Church's' position was not properly grounded due to multiplicity of players, some of which like the politicians have different objects altogether.

\section{The Ufungamano Initiative (1999-2002)}

With intensified NEC protests all over the country owing to the cooptation of major political players including a section of Right Wing Evangelical Protestant Churches by the regime, the mainline Churches including Anglican, Methodist, Presbyterian, and Catholic coalesced under the banner of Ufungamano Initiative to spearhead comprehensive constitutional reforms.

On the emergence of Ufungamano Initiative, Jacob Mati poignantly points out that:

The Ufungamano Initiative was an offshoot of NCEC. Part of its emergence was because NCEC was perceived to be very radical. There was therefore a need in the view of the international donor community and the political elite as a whole, and not just the opposition, together with the religious groups, to kind of de-radicalize the contention (Mati, 2012;120).

This new development was characterized by the endemic acrimony that had developed between the government, opposition parties and Civil society groups; religious community included on the one hand. Henceforth limiting opportunities for comprehensive constitution reforms (Chitris, O.I 08/07/2015). Interestingly, all parties were invited to convene at Ufungamano House (an ecumenical building owned by NCCK and Catholic Church) for way forward including KANU which had been a stumbling block towards constitutional review. On $15^{\text {th }}$ December, 1999, Gitari with other religious leaders drawn mainly from Catholic, Methodist, NCCK, and Hindu Council alongside the Civil Society Groups (CSGs) attended the first Stakeholders forum at Ufungamano House (Ireri, O.I; 14/04/2015). This meeting took two days and it was chaired by former Archbishop David Gitari of the Anglican Church of Kenya (ACK) that gave birth to a Steering Council (SC) of 36 Religious leaders who were committed to "a people driven Constitutional 
Reform Process in Kenya (Gitari et al., 2002;93)."Gideon Ireri, former bishop of Anglican Diocese of Mbeere (1997-2008) outlined the objective of the Steering Council as follows:-i) to provide leadership, guidance and to give direction and policy of the aspirations of Religious community, and ii) to foster dialogue and understanding amongst themselves and amongst different sections of Kenya society in Constitution Review process (Ireri, O.I; 14/04/2015). At the end of this convention, they promised to use mosques, temples and Churches as forums for civic education, consultation and collating views for the constitutional review process (Murunga \& Nasong'o, 2007;46).

Apart from the Steering Council which was the final decision making organ, the meeting resolved to form the People's Commission of Kenya (PCK) which came to existence in June 2000 to deal with collecting of views and preparation of the draft. This body was chaired by the late Dr. Ooki Ombaka (Ireri, O.I; 14/04/2015). But Gitari continued chairing the council meetings, however, later it was unanimously agreed that the meeting should be cochaired on rotational basis among the heads of the various religious communities (Ibid). Rashmin Chitris claimed that this decision was arrived at to avoid any leadership wrangles that have wrecked other social movements (Chitris, O.I 08/07/2015).

In countering the Ufungamano movement, the government launched a parallel parliamentary constitutional review process through Inter-Parties Parliamentary Group (IPPG) under the chairmanship of Raila Odinga, the party leader of NDP (Chitris, O.I 08/07/2015). However, according to Mati these new developments were significant as they opened fertile grounds for further contestation between the Ufungamano Initiative comprising members of the mainline Churches, Civil Society Organisations (CSOs), and some opposition parties, and on the other side, the parliamentary select committee being supported by Raila- led NDP and some of the regime's traditional partners:- Evangelical Fellowship of Kenya (EFK) and its member Churches including Africa Inland Church (AIC), the African Independent Pentecostal Church of Africa (AIPCA), the Deliverance Church, Redeemed Gospel Church of Kenya, and the Church of God in East Africa (Mati, 2012;148). However, the division of the Church between the two factions pulling towards different directions, only help to cement the narrative that the Church in Kenya as elsewhere in Africa have never responded with 'one prophetic voice' in the public culture. Perturbed by this normative behavior, Damaris Parsitau blamed the emergence of Neo-Pentecostal Churches as having contributed to the Church's mixed signals in public sphere (Parsitau, 2011;123-145).

Despite such challenges, David Gitari was appointed as one of the spokesperson of the Steering Council (SC) on $15^{\text {th }}$ March, 2000 to keep the public through the media, fully informed on the progress of the Ufungamano 
Initiative (Gitari et al., 2002;26)." It appears that Ufungamano Initiative was the brainchild of Gitari among other religious leaders; however, this is contested by both Gideon Ireri and Rashmin Chitris. Bishop Ireri in an interview with the researcher claimed that Gitari did not attend most meetings of the Ufungamano Initiative hence such an individual could not be entrusted to articulate the issues of the Initiative (Ireri, O.I; 14/04/2015). ${ }^{11}$ Whilst Rashmin Chitris argues that Ufungamano was a dream of Kenyans and religious leaders were bound by common interest and therefore, they were issuing joint press Statements (Chitris, O.I 08/07/2015). ${ }^{12}$

A critical analysis of the minutes of Ufungamano Initiative clearly corroborated this assertion by Gideon Ireri that most meetings between 2001 and 2002 were not regularly attended by Gitari. ${ }^{13}$ What is intriguing is the fact that someone who is credited for being one of the founder member(s) of an organization could lose interest in the activities of the same organization which he helped to build. This raises a number of questions on the Ufungamano Initiative. For instance, was there a simmering contestation between moderates and radicals or among the representatives? What could have made Gitari to lose enthusiasm with Ufungamano or had he been compromised by the regime?

In an attempt to unpack some of the underlying issues, Bishop Ireri admitted that Gitari was not comfortable with Rev. Mutava Musyimi (current Member of Parliament for Mbeere Constituency) by then the secretary of the movement. ${ }^{14}$ This was compounded by the fact that Hon. Mutava Musyimi,

${ }^{11}$ Gideon Ireri was one of the representatives of ACK in the Ufungamano Initiative and played a leading role especially in the post-Gitari era (2002-2008). He doubled up as the Bishop of Mbeere diocese (1998- 2008) and at one point he served as a co-chair with Rashmin Chitris.

${ }^{12}$ Rashmin Chitris in a personal communication with the researcher elucidated this further that Mutava Musyimi seemed to have been the undisputed spoke-person of Ufungamano Initiative, however, the Steering Council which was composed mainly of religious leaders hold joint press conferences. He argues that the joint press conference does not downplay the key role that Gitari played in articulating the agenda of the Initiative.

13 I schemed through the following minutes of Steering Committee meetings held at Ufungamano House on various dates such as; Ufungamano Initiative Stakeholder Council Meeting (19/01/2000); Ufungamano Initiative Steering Council meeting (08/08/2000) and Ufungamano Initiative Report of March 21 2001, the Plenary of Stakeholders meeting, (21/03/2001). In all these meeting(s), David Gitari was absent with apology whilst in others his name was completely missing. However, in an interview with Rashmin Chitris, he argues that since the steering Council was dominated by heads of various religious community it was likely that they were engaged in other religious duties and their absenteeism should not be construed as lack of interest. Interestingly, he admitted that some members of the Ufungamano were not happy with Mutava Musyimi as it seemed that he was interested in achieving the objectives of NCCK at the expense of broader aims of the Initiative.

${ }^{14}$ Gideon Ireri claimed that Gitari ordained Mutava Musyimi in 1989 by then Gitari was the incumbent bishop of Mt. Kenya East diocese. However, during the Ufungamano Initiative, he was serving as the archbishop of ACK and Mutava Musyimi would dismiss him outright 
one of the co-conveners of the Ufungamano Initiative could dismiss Gitari during the meetings without considering his views as he regarded him to be too radical. He further observed that Gitari was a forerunner in many activities and could not allow others to lead him (Ireri, O.I; 14/04/2015). Owing to the fact that Bishop Gitari had ordained Mutava Musyimi as a priest and helped him to rise through the ranks within NCCK and eventually becoming the Secretary General of the organization, according to Gideon Ireri, the prelate expected Mutava to show some respect [sic] to him as the Archbishop (Ibid). However, this was not the case, Mati argues that Mutava Musyimi usurp the powers within the movement by the virtue of his position in NCCK and overshadowed the Steering Council (SC) which was one of the top decision making organ (Mati, 2012;252). In the end, Mutava became the undisputed spokesperson of Ufungamano.

The first hypothesis is sharply contested by John Mararo who claimed that Gitari as the Archbishop of ACK (1997-2002) was involved in so many ecumenical movements and activities (Mararo, O.I; 30/01/2015). Therefore, the possibility of being absent from some meetings was inevitable; however, that does not in any way show that he lacked interest (Ibid). Interestingly, Mararo admitted that when it comes to leadership, Gitari was always in forefront and could not allow others to lead him (Mararo, O.I; 30/01/2015). Both arguments are tenable. In fact, Ufungamano as a corporate body of religious communities and leaders was not immune to internal division and conflicts that are inherent in CSOs. Mati astutely observes that "the Ufungamano Initiative was riddled with many contradictions and cleavages, which served both as opportunities but also constraints in its work (Mati, 2013). Particularly, the existing mistrust between radical civil society and opposition political elites offered an opportunity for moderation and arbitration by the religious leadership (Ibid). The catalytic role of the religious community forged unity that was necessary for any meaningful progress.

In the absence of universal unity within the Christian community as seen in Gitari and Mutavas' case, mistrusts developed and the radical secular civil society composed mainly of young lawyers, Nairobi University students, and other urban middle class dwellers felt dissatisfied with religious leadership in the Initiative (Chitris, O.I; 08/07/2015. Some felt that some of the clergy were working in cohort with the State and derailing the process. Mutua supports this view regarding religious leaders being sympathizers of the State (Mutua, 2008). In one incident, Gitari was approached by two senior political leaders who happened to be members of ACK. Although the motive of their

during the meetings. He augured that this did not go well with Gitari. Henceforth, he started missing meetings. 
visit is unknown, but according to Karanja they were sent by the regime to persuade him to denounce the activities of Ufungamano (Karanja, 2008;8992). He argued that the government targeted Gitari because he was a powerful and influential member of the religious group (Ibid).

On the one hand, it is proper to argue that the radical approach of secular civil society, academic activists and student organizations was unhealthy for the incubation of democratic reforms in the country hence the moderation role of the religious leaders was a necessity for reforms to materialize (Ufungamano Initiative, 1999;38/99). This, I have argued was done through Episcopal conferences, Newsletters, political sermons, mass media, pastoral letters and sometimes through closed-door negotiations to avoid any fall-out. As Ufungamano Initiative was moving around the country collecting and colligating peoples view for constitutional proposal, the Railaled Parliamentary Select Committee on Constitutional Reform was not leaving anything to chance as they put in place an Enabling Act through Parliament in October 2000 (Wandera, 2011). Subsequently, the Constitution of Kenya Review Commission (CKRC) was established under the chairmanship of Yash Paul Ghai (CKRC, 2002b;2). This led to a new wave of contention between Ufungamano stakeholders and the State led process, as Ghai demanded for the merger of the two processes. Despite such struggles between the Ufungamano Initiative and the Ghai-led CKRC, the CKRC enjoyed statutory legitimacy and ended up negotiating successfully for a merger with the Ufungamano Initiative (Mitulla, 2003).

From the empirical analysis, it is clear that Gitari might not have been the captain of Ufungamano Initiatives due to cases of absenteeism as revealed by the minutes of the Steering Council (SC) but he still remains as one of the engineers that dug the tunnels by which the entire process of a peoples driven constitution got its bearing. Arguably, whilst the constitutional change processes hit a snag prior the Ufungamano Initiative due to unnecessary partisan politics and interest as validated by the empirical data, it is evident that the Ufungamano achieved some of its goals. Since, it managed to initiate a parallel people driven process towards constitution review. This however, according to John Chesworth, impelled the Moi regime to initiate the longexpected process of establishing an official commission namely CKRC (Chesworth, 2009;164).

In summary, Ufungamano Initiative managed to bring over 50 Civil Society Organisations (CSO) together as it struck a middle ground between radical and moderate members of the movement in accord to the reconstruction model advanced in this study. Despite class, ideological, and ethnic polarization that have characterized other social movements, Mati argues that the success of the Ufungamano Initiative in bringing different forces together as in the question of constitutional review suggests that 
'broad based social movements are possible when the resultant movement or alliance can offer a middle ground coalition that has the ability to mopup the various competing interests (Mati, 2013; 235-254)'. Based on this assertion, the clergy, and other religious leaders such as Gitari played a central role in breaking a middle ground between the divergent forces into a common ground for constitutional reforms.

\section{$\circ$ Critical Appraisal of Reconstruction Model in light of Constitutional Development}

This article took the view that liberation and reconstruction models are twin un-identical frameworks of analysing African challenges in post-cold war period and beyond. The double paradigm was sufficient historio-analytic model for examining the complex interactions between the Ufungamano Initiative and the State as undertaken by the Church and other religious leaders in constitution making process. To buttress the significance of liberation praxis in the agitation for constitutional reforms, Mati observes:

Many of the so-called radical clergy in Kenya borrowed a leaf from the Rev. Martin Luther King Jr. who once said: 'any religion that is not concerned about the poor and disadvantaged, the slums that damn them, the economic conditions that strangle them, and the social conditions that cripple them, is a spiritually moribund religion awaiting burial (Mati, 2012;167).'

This exhortation only serves to establish that liberation and reconstruction models are 'cyclical theologies' in Africa, and in response to either repression or intransigence on the part of an authoritarian State. Conversely, this contradicts Mugambi's declaration of a paradigm shift to some extent since socio-political context, and the State behaviour on one hand determines the appropriateness of the paradigm for engagement. Making some to be minor whilst others dominant. Similar, sentiments are advanced by Julius Gathogo on 'Major Versus Minor' paradigms in his 'post-mortem' analysis of Jesse Mugambi's reconstruction theory (Gathogo, 2008). The dilemma we might face henceforth; who and how is the appropriate model of Church-State engagement determined? Who steers the process especially in a socioculturally dynamic society such as Kenya? The common denominator of these empirical questions is that they point to some limitations of the proposal which is beyond the scope of this article.

In terms of constitutional development discussed under the Ufungamano Initiative, Jesse Mugambi glorified reconstruction model when he said:

This theology should be reconstructive rather than destructive, inclusive rather than exclusive, complementary rather than 
competitive; integrative rather than disintegrative; programme driven rather than project-driven; people centred rather than institution-centred; deed-oriented rather than word-oriented; participatory rather than autocratic; regenerative rather than confrontational; consultative rather than impositional (Mugambi,1995; XV).

In view of the above exposition, Valentin Dedji argues that theology of reconstruction is "an inter-faith and inter-denominational enterprise (Dedji, 2003;5)." The article found both statements to be in accord to the constitutional reforms as undertaken by the religious community in consolidation of Kenya's democracy. The Ufungamano Initiative was inclusive as it cut across many religious faith and denominations. Mati exemplifies this further when he avers that the Initiative had a total of 54 organisations running from grassroot community organisations to middle class civil society groups (Mati, 2013). The religious community included: United Methodist Churches of Kenya (UMCK), Anglican Church of Kenya (ACK), Organization of African Instituted Churches (OAIC), Hindu Council of Kenya (HCK), Presbyterian Church of East Africa (PCEA) and Supreme Council of Kenya Muslims- SUPKEM (Ufungamano Initiative, 2001/21). They took the struggle for constitutional reforms within as part of the reconstruction agenda set by African theo-philosopher, Jesse Mugambi.

Viewed broadly, the article is also alive to the fact that constitutional reforms cannot be sufficiently conceptualized under reconstruction ${ }^{15}$ praxis per se. Owing to heterogeneity of players in the reforms train as reflected on the constituencies that were represented during the Ufungamano Initiative and the street protests. Most likely the call for reforms was in tandem with Wilfred Cantwell Smith and John Hike theory of religious pluralism as well. Which set on the premise that Christianity as a religion is not necessarily the be-all and end- all of all religion and religious trajectories (Smith, 1979). This ecumenical approach puts much emphasis on religious dialogue. Similar

15 The study takes this precaution in line to Elelwani Bethuel Farisanis' (2003:41) critique; that in adopting Reconstruction as the new theological paradigm, one needs to be careful with the Ezra-Nehemiah text as it is "biased against the am haaretz." He champions for a critical re-reading of Ezra-Nehemiah text (Farisani 2003: 48). According to Farisani as cited by Gathogo Julius, uncritical reading refers to any reading of the Bible which is short of thorough exegetical inquiry; for it can be used to marginalize and thereby exclude the am haaretz of our times in national building. How true is this for our case? In constitutional making process public participation is important as seen in the Ufungamano Initiative which was a conglomeration of many civil society groups inclusive of religious leaders, politicians and grass root supporters. Consequently, introducing Wilfred Cantwell and John Hike theory of Religious pluralism makes Ufungamano a all-inclusive social movement and eliminates Farisanis' argument on reconstruction model in the struggle for constitution making and nation building. (See Wilfred Cantwell Smith (1979). 
arguments are also advanced by Tsawe Munga wa Chidongo as he blamed the 'superiority syndrome' on Christianity and Islam and especially by their failure to enter into constructive dialogue with African Indigenous Religion (AIR) in the contemporary development of Kenya (Chidongo, 2014;102-114). The Ufungamano Initiative although marked with numerous challenges was a success of the reconstruction paradigm in Kenya.

\section{Conclusion}

The article argued that despite the opening of space to multi party democracy from single party dictatorship, the transformation and transition of the State to that end was severely hindered right from the beginning. It observed that the quest for meaningful constitutional reforms was scuttled by both the opposition and the State as the reform agenda became a class struggle rather than people driven initiative. Ethnicity, political patronage and narrow interest all played out to derail the reformation process. This article established that religious leader's initiative to mediate over constitution making process was characterised by infiltration by the State apparatus with an attempt to coopt some of them. In this scheme, politicians were not left out as majority of them capitulated to State antics to derail the much needed reforms. Despite such bottlenecks, notable religious leaders from the Church such as David Gitari, Henry Okullu, Gideon Ireri, and Timothy Njoya played a critical role in the pursuit for democratic space through constitutional reforms. In particular, Gitari's active role during the cleansing ceremony at the Nairobi ACK Cathedral and the political sermon vis a' vis 'Mene Mene Tekel Uparsin,' threatened the regime as it exposed its brutality and at the same time legitimized the call for constitutional reforms. The epitome of these developments was seen in the Ufungamano Initiative which was a religious umbrella organization including other religious leaders such as those from Islam, and Hindu religions. As a dynamic religious movement with wide constituencies, Ufungamano Initiative was prone to diverse interests and leadership wrangles and therefore the primary goal might have been chopped off by secondary objectives marked by partisan interests. On the other hand, its' heterogeneity in composition proved to be a double hedged sword to success as it opened a 'battlefield of interests' geared towards recognition and attention which eventually clouded its' constitutional reform agenda. In summation, the article argued that the Church leaders resolve for reforms in the country proved the critics of Jesse Mugambi wrong since their unity under Ufungamano and merger under the Constitution of Kenya Review Commission (CKRC) left no room for anything less than constitutional reforms. 


\section{Acknowledgement}

I would like to sincerely thank Prof. Dr. Stephen Muoki Joshua an Associate Professor of Church History at Pwani University (Kenya) and Dr. Julius Gathogo of Kenyatta University for their honest review of this article since it significantly contributed to its current form.

\section{References:}

1. Brown, S. (2001). Authoritarian leaders and multiparty elections in Africa: How foreign Donors help to keep Kenya's Daniel Arap Moi in power.' Third World Quarterly. Vol. 22 (5), 725-739.

2. Chesworth, J. (2009). The Church and Islam: Vyama Vingi (Multipartism) and the Ufungamano Talks, In B.Knighton (Eds), Religion and Politics in Kenya: Essays in Honor of a Meddlesome priest ( pp.155-180) New York: Palgrave, Macmillan.

3. Chidongo, M.T. (2014). Theology, innovation and Society: Towards developing Dialogical Theology for African society; Kabarak Journal of Research \& Innovation (KJRI) Vol. 2 (1) 2014.

4. CKRC, (2002). Constitution of Kenya Review Commission. "The People's Choice: The Report of the Constitution of Kenya Review Commission. CKRC. Nairobi, Kenya.

5. Daily Nation (1993) January 4: Church Calls for peace despite Election Malpractice. Nairobi, Kenya.

6. Dedji, V. (2003). Reconstruction and Renewal in African Christian theology. Nairobi: Acton.

7. Farisani, E.B. (2002). The use of Ezra- Nehemiah in a quest for a theology of renewal, transformation and reconstruction in the (South) African context. PhD Dissertation. Durban: University of Natal.

8. Gathogo, J.M. (2008). Liberation and Reconstruction in the works of J.N.K Mugambi: A critical analysis in African Theology. Unpublished PhD Thesis: University of Natal.

9. Gitari, D.M. \& et al (2002) Eight Great Years: Achievement of the Ministry of Archbishop David Gitari. Provincial Liturgical Editor.

10. _ (2014) Troubled But Not Destroyed: Autobiography of Dr David M. Gitari, Retired Archbishop of the Anglican Church of Kenya. Isaac publishing.

11. Horowitz, D (1994). "Democratization in Divided Societies", in Diamond, Larry and Marc F.

12. Plattner (eds), Nationalism, Ethnic conflict and Democratization. Baltimore: Johns Hopkins University Press.

13. Kangude, Kä Mana, (2002) Christians and Churches of Africa envisioning the future: Salvation in Jesus Christ and the building of a new African society. Oxford: Regnum. 
14. Kapinde, S. (2015). Prophetic Church Leadership in Kenya's Democratic Process between 1986 and 2002: A case of the Most Rev. Archbishop David Gitari. Unpublished Master Thesis Dissertation of Pwani University, Kenya.

15. Karanja, J (2008). Evangelical Attitudes toward Democracy in Kenya, Terence Ranger, (ed) In Evangelical Christianity and Democracy in Africa, 67-93. Oxford: Oxford University Press.

16. Katumanga, M. (1999). Civil Society and the Politics of Constitutional Reforms in Kenya: A Case Study of The National Convention Executive Council (NCEC). Series on Alternative Research in East Africa (SAREAT).Availableonlineathttp://info.worldbank.org/etools/docs/li brary/108351/session7b.pdf.Accessed on June 62015.

17. Maluleke, TS. (1994). The proposal for a Theology of Reconstruction: A critical Appraisal. Missionalia 22 (3), pp 245-258.

18. Mati, JM. (2013). Antinomies in the struggle for the transformation of the Kenyan constitution (1990-2010), Journal of Contemporary African Studies, 31:2, pp 235-254, DOI: $10.1080 / 02589001.2013 .785145$

19. (2012) The power and limits of social movements in promoting political and constitutional change: The case of the Ufungamano Initiative in Kenya (1999-2005). Unpublished PhD Dissertation, University of the Witwatersrand, Johannesburg, South Africa.

20. Mitulla, W. (2003). Gender Inclusion in Transition Politics: A Review and Critique of Women's Engagement' in W. Oyugi, P. Wanyande, P and O.C, Mbai [eds] The Politics of Transition in Kenya: From KANU to NARC (pp212-235) Nairobi: Heinrich Boll Foundation.

21. Mugambi, J.K.N. (1991)."The Future of the Church and the Church of the future in Africa" In J. B. Chipenda, A. Karamaga, J.N.K Mugambi \& C. K. Omari, (Eds) The Church of Africa: Towards a Theology of Reconstruction (Nairobi: A.A.C.C)

22. (1995) From Liberation to Reconstruction: African Christian Theology After the Cold War. Nairobi. EAEP.

23. Muoki, S and Kapinde, S (2016) "Pulpit Power" and the unrelenting voice of Archbishop David Gitari in the democratization of Kenya, 1986 to 1991. Historia 61, 2, November (2016), pp 79-100.

24. Mutua, M. (2008) Kenya's Quest For Democracy: Taming leviathan. Kampala: Fountain Publishers. 
25. Mutunga, W. (1999) Constitution-Making from the Middle: Civil Society and Transition Politics in Kenya, 1992-1997, Nairobi: MWENGO and SAREAT.

26. (2013). A TRIBUTE: Listening to Gitari preach his best Sermon Ever, Sunday Nation, October 6, 2013

27. Murunga, G. \& Nasong'o, S. (2007). Kenya: The struggle for Democracy. Zed books Ltd 7 Cynthia street London.UK.

28. Ng'ethe, N. \& Katumanga, M. (2003). Transition and the Politics of Constitution Making: A Comparative Study of Uganda, South Africa And Kenya.' In W. Oyugi, W., P. Wanyande, and O.C. Mbai, (Eds.) The Politics of Transition in Kenya: from KANU to NARC, (pp 345381). Nairobi: Heinrich Böll Foundation.

29. Njonjo, M. (2011). Reflecting on Church-State relationship in Kenya. In M.N, Ndarangwi, (ed.), Jesus and Ubuntu: exploring the social impact of Christianity in Africa. Africa World Press, Trenton, New Jersey (pp 123-145). Available: www.africaworldpressbooks.com

30. Okullu, J (1997). Quest for Justice: An Autobiography of Bishop Henry Okullu. Kisumu: Shalom Publishers.

31. Parsitau, DS. (2011). Rethinking the socio political impact and significance of Pentecostal Christianity in Kenya (19702009), in Ndarangwi, MN (ed.), Jesus and Ubuntu: exploring the social impact of Christianity in Africa. Trenton, New Jersey: Africa World Press.

32. Petersen, R. (1991). Towards a South African theology of NonRacialism. Journal of Theology for Southern Africa, (No.77),18-26.

33. Press, R. (2013). Individual and Organizational Human Rights Activism in Liberia, Sierra Leone, and Kenya, Journal of Human Rights, 12:4, 447-468, DOI:10.1080/14754835.2013.812466

34. Smith, W.C. (1979). Faith and Belief. Princeton, NJ: Princeton University Press.

35. Throup, D. W. \& Hornsby, C. (1998). Multi-Party Politics in Kenya: The Kenyatta and Moi States and the Triumph of the System in the 1992 Election. Oxford: James Currey.

36. Ufungamano Initiative, (1999). Minute 38/99 of the meeting of the Religious Leaders in Kenya discussing the Constitution of Kenya Review Process held on Monday, November 22, 1999 at the Ufungamano House, Nairobi, Kenya.

37. Ufungamano Initiative, (2001). Minutes of the Ufungamano Initiative. Report of March 21 2001, the Plenary of Stakeholders meeting. Nairobi, Kenya.

38. Villa-Vincencio, C. (1992) A Theology of Reconstruction: Nationbuilding and Human Rights. Cambridge: Cambridge University Press. 
39. Wandera, J. (2011). "Anglican Responses to Kadhis Courts in Kenya." In A. Tayob \& J Wandera (Ed) Constitutional Review in Kenya and Kadhi Courts: Selected Papers Presented at Workshop, 20 March 2010, (pp39-48). Limuru, Kenya.

\section{Oral Interviews}

40. James Samuel Mathenge, digital recording, interview by the author at ACK GUEST HOUSE (Nairobi) on 29/01/2015

41. Canon John Mararo, digital recording, interview by the author, St Thomas Kerugoya (Kirinyaga) on 30/01/2015 and 14/04/2015

42. Ephantus Muriuki, digital recording, interview by the author, St Thomas Kerugoya (Kirinyaga) on 30/01/2015

43. Julius Gathogo, digital recording, interview by the author, Kenyatta University (Coast Campus) on 19/02/2015

44. Rev. Canon Gideon Ireri, digital recording, interview by the author at G-8 Retreat Centre, Mbeere on 10/04/2015 and 14/04/2015

45. Rashmin Chitris, telephonic interview by the author on 08/07/2015

46. Timothy Njoya an interview by Robert Press at Nairobi, Kenya on July 29, 2002 (Available at Library of Congress). 